\title{
Nalar dan Iman dalam Kehidupan Beragama: Dikotomi atau Harmoni
}

Edison R. L. Tinambunan

Sekolah Tinggi Filsafat Widya Sasana, Malang, Jawa Timur

edisontinambunan@gmail.com

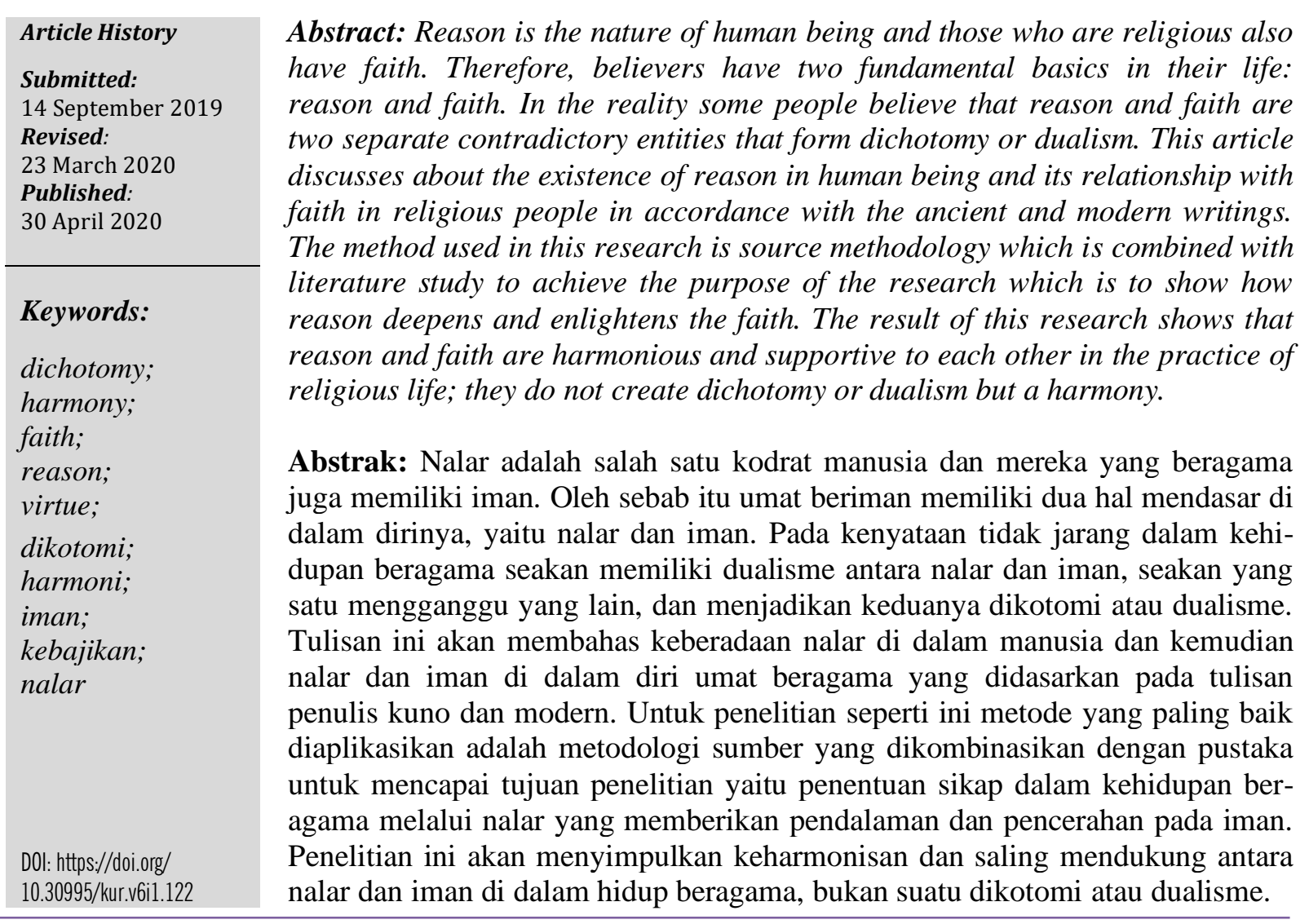

\section{Pendahuluan}

Saat ini Indonesia dan juga dunia sedang dilanda pandemi Covid-19 (Corona), walaupun di beberapa negara jumlah terinfeksi sudah mulai menurun. ${ }^{1}$ Untuk mencegah penyebarannya, karena sampai saat ini para ilmuan masih berjuang untuk menemukan vaksin sebagai pencegah ampuh, diterapkan pemutusan mata rantai. Salah satu cara untuk tujuan itu adalah menghindari perkumpulan di sekolah, tempat kerja dan bahkan di tempat ibadah. Untuk itu, presiden Republik Indonesia Joko Widodo meminta masyarakat Indonesia agar bekerja, belajar dan beribadah di rumah. ${ }^{2}$ Sebagai orang beriman, beribadah di rumah adalah sangat berat. Berdoa di rumah atau di mana saja adalah praktik yang biasa dilaksanakan, tetapi

\footnotetext{
${ }^{1}$ Saat tulisan ini ditulis, terinfeksi pandemi ini di Indonesia masih sedang mengalami grafik kenaikan.

${ }^{2}$ Ihsanuddin, "Jokowi: Kerja dari Rumah, Belajar dari Rumah, Ibadah dari Rumah Perlu Digencarkan", Kompas, Editor Bayu Galih, 16 Maret, 2020, https://nasional.kompas.com/read/2020/03/16/15454571/jokowikerja-dari-rumah-belajar-dari-rumah-ibadah-di-rumah-perlu-digencarkan (diakses pada 29-4-2020).
} 
beribadah di rumah, walaupun dengan menggunakan bantuan sarana media sosial, kurang bisa diterima sehubungan dengan iman, karena berbagai alasan. Dalam peribadahan misalnya, jemaah membutuhkan kontak langsung dengan pemimpin ibadah dan berada di tempat ibadah mendukung suasana, oleh sebab itu semestinya praktik ibadah di rumah pada hari Minggu atau hari lain adalah kurang mendukung. Akan tetapi, jika orang mulai menggunakan nalar, mestinya prinsip seperti itu tidak dipertahankan karena berbagai aspek. Dalam suasana dan situasi seperti ini, nalar dibutuhkan untuk membantu iman dalam kehidupan beragama.

Dengan peraturan yang diaplikasikan, dari aspek keagamaan mungkin sulit diterima, akan tetapi dari aspek untuk tujuan agar tidak membahayakan diri dan juga orang lain, praktik ibadat di rumah menjadi solusi. Oleh sebab itu, sebagai orang yang memiliki nalar dan sebagai orang yang memiliki iman, situasi ini bisa menimbulkan dikotomi di dalam diri sendiri. Jika orang tidak bisa mengendalikannya, dalam arti mementingkan yang satu dari yang lainnya atau menganggap yang satu mampu mengatasi yang lainnya, maka bisa mengakibatkan kefatalan.

Nalar dan iman adalah dua unsur yang tinggal di dalam diri setiap orang beragama. Permasalahan yang tampil adalah: Apakah nalar dan iman menimbulkan dikotomi? Apakah keduanya bisa memiliki keharmonisan? Dalam situasi konkret di hadapan mata (apa pun itu), sebagai orang beragama, harus berbuat apa dan bagaimana menyikapinya? Berbicara mengenai nalar, mau tidak mau harus melihat titik tolaknya dari sudut filsafat. Plato adalah orang yang pertama memberikan pembahasan mengenai nalar yang kemudian diikuti oleh para filsuf sesudah dia seperti Aristoteles dan lainnya. Dalam pertemuan dengan filsafat, Kristen melihat aspek nalar dalam hubungannya dengan iman. Agustinus dari Hippo adalah salah satu Kristen yang berusaha menunjukkan hubungan nalar dan iman, yang kemudian diikuti oleh Anselmus, yang berusaha mempertegas dan memperluas pemikiran pendahulunya itu. Kemudian René Descartes seakan menyimpulkan pemikiran Agustinus dan Anselmus melalui metode filosofisnya Cogito ergo sum (saya berpikir, oleh sebab itu saya ada). Mereka bertiga ini sungguh menyadari bahwa nalar dan iman memengaruhi hidup. Baik nalar maupun iman tidak terpisahkan satu dengan lainnya.

Tujuan penelitian ini adalah untuk sampai pada suatu pilihan sikap sebagai orang beragama untuk menghadapi setiap peristiwa hidup, terlebih saat harus mengambil keputusan bukan saja pandemi Covid-19 yang kebetulan sedang melanda Indonesia. Kalau seseorang sungguh menyadari dirinya, maka ia akan tahu bahwa setiap saat ia harus dihadapkan pada suatu keputusan yang membutuhkan nalar. Untuk sampai pada tujuan ini, penelitian akan didasarkan pada tulisan penulis (sumber utama) dan studi terkait sebagai rujukan dan titik tolak, karena mereka ini telah membuka pintu untuk pemahaman nalar dan iman. Oleh sebab itu berdasarkan tulisan mereka ini, penelitian akan beranjak untuk memberikan suatu temuan sehubungan dengan nalar dan iman untuk menghadapi setiap fenomena yang dialami, terlebih pandemi saat ini.

\section{Metode Penelitian}

Guna memberikan jawaban atas permasalahan dan tujuan yang akan dicapai melalui tulisan ini, penulis menggunakan metodologi sumber yang kemudian dilanjutkan dengan beberapa 
studi terkait yang berhubungan dengan pokok bahasan. Metodologi sumber ialah bahwa penulis merujuk pada tulisan kuno (klasik) sebagai pencetus bahasan nalar dan iman. Ciri khas metodologi ini adalah penggunaan tulisan penulis dalam bahasa asli atau terjemahan yang dapat dipertanggungjawabkan. Teks bahasa penulis kuno dapat dilihat di dalam catatan kaki dan referensi. Penelitian dengan metode ini adalah cara terbaik untuk menggali konten argumen dan mengaplikasikannya di dalam kekinian untuk mempresentasikan aspek yang bisa berkaitan dengan hidup saat ini.

Dalam perjalanan waktu, banyak penulis telah melaksanakan studi dari penulis kuno tersebut mengenai tema yang diangkat, akan tetapi penulis hanya memilih beberapa saja baik itu dari buku maupun jurnal untuk sampai pada tujuan penulisan. Hal ini menunjukkan bahwa tema yang diangkat adalah tetap aktual dalam perjalanan waktu, walaupun penulis kuno itu telah hidup sangat jauh dari saat ini. Metode ini sering dikenal dengan studi pustaka yang adalah cara untuk mempertajam deskripsi analisis pesan penulis. Oleh sebab itu, penulis akan menggunakan kombinasi metodologi sumber dan pustaka dalam penyajian penelitian ini.

\section{Pembahasan}

Penelitian akan nalar adalah sudah sangat klasik sekali, artinya adalah bahwa tema ini sudah dibahas sejak zaman Yunani kuno. Salah satu penulis yang sangat sentral membicarakan mengenai tema ini adalah Plato yang banyak ditemukan di dalam tulisannya. Penulis sebelum dia pasti juga telah menyinggung tema ini, tetapi sejak kehadiran Plato, nalar menjadi sangat penting.

\section{Nalar}

Dalam tulisannya yang berjudul Protagoras, Plato mengatakan bahwa nalar adalah kodrat manusia, ${ }^{3}$ yang berasal dari logos, yang membedakannya dari ciptaan lain. Inilah kekhasan manusia yang tidak dimiliki oleh ciptaan lain yang menjadikannya sebagai identitas dari yang lainnya di dunia ini. Artinya ialah bahwa hanya manusia memiliki nalar yang menjadikannya sebagai kodrat, sedangkan ciptaan lain, ${ }^{4}$ memiliki ciri khas yang membedakannya dari manusia. Kodrat ini menjadikan manusia lebih tinggi kualitasnya dari ciptaan lain. Alasan Plato menjadikan nalar sebagai kodrat manusia adalah karena membuatnya mirip dengan yang tertinggi (logos) dan dengan nalar tersebut mendekatkannya dengan yang tertinggi itu. ${ }^{5}$

Sampai pada poin ini, fungsi nalar tersebut belum tampak untuk menjadikannya sebagai kodrat manusia, karena hanya menunjukkan keberadaannya di dalam diri setiap orang. Manusia memiliki keinginan, kenikmatan, rasa sakit, kasih, rasa takut, kebutuhan dan aspekaspek kehidupan lain yang memengaruhinya. Untuk itu dibutuhkan nalar yang berusaha untuk mengorganisasi semua aspek itu agar manusia mampu memiliki sikap kesatuan untuk mengambil suatu tindakan bagi dirinya. Misalnya, jika seseorang ingin memutuskan sesuatu, ia menggunakan nalar untuk mempertimbangkan aspek positif dan negatif dalam setiap kepu-

${ }^{3}$ Plato, Protagoras 358a-d: Complete Works, ed. John M. Cooper (Indianapolis / Cambridge: Hackett Publishing Company, 1997), 786-787.

${ }^{4}$ Plato, Definitions 415a: Complete Works, 1684.

${ }^{5}$ Plato, Phaedo 75c-76a: Complete Works, 66-67. 
tusan. Dengan pertimbangan itu, orang kemudian memiliki alasan untuk menentukan sikap. Fungsi lain yang tidak kalah penting dari nalar adalah untuk mengatur dirinya agar melaksanakan perbuatan baik atau menghindari yang jahat dan sikap lainnya atau untuk kebajikan. ${ }^{6}$ Dengan cara itu, orang bertindak tidak berdasarkan komando dari orang lain, apa lagi paksaan, tetapi diputuskan oleh diri sendiri dengan penggunaan nalar yang dimiliki. Dengan demikian nalar ini menjadikan setiap orang bebas dari tekanan orang lain di dalam hidup, ${ }^{7}$ karena setiap orang pada dasarnya telah memiliki kemampuan untuk hidupnya dan mempertanggungjawabkannya.

Berdasarkan fungsi nalar ini, pada prinsipnya setiap orang memiliki kemampuan untuk menentukan bagi dirinya sendiri, tanpa campur tangan dari pemikiran orang lain. Bahkan dalam situasi sulit pun berkat nalar yang dimiliki, memampukannya untuk mengambil langkah yang hendak ditempuh. ${ }^{8}$ Orang lain yang berada di luar dirinya, berdasarkan pemikiran ini, berfungsi hanya sebagai pencerah nalar yang sering dikenal dengan nasihat, agar orang tersebut dimampukan untuk menentukan sikap. Artinya adalah orang lain yang berada di luar diri sendiri tidak bertindak sebagai orang yang memutuskan, tetapi dapat menjadi orang yang memengaruhi keputusan. Prinsip yang mau ditekankan Plato adalah bahwa nalar itu pada dasarnya subjektif yang menjadi kodrat manusia yang menjadikannya menjadi bijak. Bagi Plato, jika setiap orang mengoptimalkan nalar di dalam dirinya, maka kebajikan tetap hadir.

Hal yang penting dalam pemikiran Plato adalah bahwa kebajikan yang dimiliki manusia lahir dari nalar atau dengan kata lain kebajikan datang dari nalar. ${ }^{9}$ Berdasarkan jalan pikiran Plato ini, rumusan yang bisa dilahirkan adalah bahwa pada dasarnya manusia itu adalah baik, karena memiliki nalar yang memberikan kebajikan. Alasannya adalah bahwa kebajikan, apa pun bentuknya, adalah selalu baik yang diaplikasikan sesuai dengan situasi yang dihadapi. Akan tetapi, tidak bisa dipungkiri, ada orang melakukan kejahatan yang secara platonis berada di luar prinsip nalar. Atau dengan pertanyaan: Mengapa orang bisa jahat atau melakukan kejahatan? Sebenarnya, Plato tidak mengidentikkan manusia dengan kejahatan, karena hal itu bukan kodratnya. Akan tetapi, jika ada orang tetap mempraktikkan kejahatan, maka orang tersebut tidak memiliki kemampuan untuk mengontrol diri pada kodratnya yang menghasilkan kebajikan. ${ }^{10}$ Atau orang tersebut berdasarkan pengaruh yang datang dari luar dirinya atau untuk demi kepuasan dan kenikmatan atau lainnya yang bukan kebajikan, memisahkan dirinya dari kebajikan. Alasan lain adalah bahwa orang tersebut melihat bahwa di luar kebajikan terdapat kepuasan atau keindahan.

Berdasarkan pembahasan pemikiran platonis ini bisa dikatakan bahwa pada dasarnya manusia adalah bukan jahat, karena memiliki kebajikan. Sementara itu kebajikan itu adalah buah dari nalar yang secara genesis berasal dari yang tertinggi yang dalam pemikiran Plato disebut dengan logos. Dengan prinsip konsep ini, Plato dan juga para filsuf lainnya berusaha

\footnotetext{
${ }^{6}$ Plato, Definitions 411d: Complete Works, 1679.

${ }^{7}$ Plato, Protagoras 352b-e: Complete Works, 782.

${ }^{8}$ Plato, Definitions 412a: Complete Works, 1679.

${ }^{9}$ Plato, Phaedo 96a-c: Complete Works, 83-84.

${ }^{10}$ Plato, Protagoras 358e: Complete Works, 787.
} 
untuk memberikan pembelajaran filsafat kepada orang agar manusia tetap memelihara nalar agar tetap menjadi orang bajik. Inilah tujuan pembelajaran filsafat. Artinya adalah bahwa berfilsafat adalah untuk hidup, yaitu hidup bajik agar sesuai dengan kodratnya. Oleh sebab itu jika orang hidup bajik, maka ia hidup menurut nalar dan ia adalah bahagia karena hidup sesuai dengan kodratnya, yaitu yang tertinggi (logos).

Di samping nalar, Plato sebenarnya juga menunjuk jiwa di dalam diri manusia yang menjadi kodrat. Bagi dia, jiwa yang berasal dari yang tertinggi (logos), harus dipelihara dari rongrongan materi, seperti tubuh, agar memiliki keselamatan, yaitu kembali kepada yang tertinggi. Fungsi nalar adalah menjadikan manusia hidup bajik, menjadikan hidup sesuai dengan kodrat yang dengan sendirinya menjadikan tubuh (materi) sesuai dengan kodratnya. Jika orang hidup sesuai dengan kodrat ini, maka jiwanya diselamatkan yaitu kembali kepada yang tertinggi. Artinya adalah bahwa nalar, tubuh dan jiwa membentuk suatu harmoni di dalam kodratnya. ${ }^{11}$ Inilah hidup sesuai dengan kodrat. Kalau ada manusia hidup tidak sesuai dengan kodrat, alasannya adalah karena nalar tidak difungsikan sesuai dengan maksudnya, sehingga menjadikan tubuh tidak sesuai dengan komando nalar.

Pemikiran platonis ini kemudian berlanjut sampai dengan kelahiran Kristen. Artinya adalah bahwa Kristen awal atau purba bertemu dan bergaul dengan para filsuf dan salah satu aliran itu adalah filsafat platonis. Dalam pertemuan itu, Kristen menjadikan filsafat sebagai bagian integral dalam beriman dan pembelajaran teologis. ${ }^{12}$ Salah satu filsuf aliran platonis yang banyak memengaruhi Kristen purba adalah Plotinus. ${ }^{13}$ Dengan bantuan pemikiran filosofis, Kristen purba ini membahas hubungan nalar dan iman di dalam hidup keagamaan.

\section{Iman untuk Nalar}

Agustinus yang sebelum menjadi Kristen belajar dan menguasai filsafat. Setelah menjadi Kristen ia menjadi teolog, ${ }^{14}$ ia memberikan suatu pembahasan di dalam tulisan mengenai hubungan antara iman dan nalar. Dalam pembahasan platonis sebelumnya, hanya menekankan peran nalar yang menjadikannya sebagai kodrat manusia. Artinya adalah bahwa dalam pembahasan itu, iman sama sekali tidak disinggung karena bukan ranahnya.

Pembahasan iman dan nalar diberikan Agustinus saat membuat penafsiran Yoh 7:17 "Barang siapa mau melakukan kehendak-Nya, ia akan tahu entah ajaran-Ku ini berasal dari Allah, entah Aku berkata-kata dari diri-Ku sendiri." Yesus mengatakan kalimat ini sebagai jawaban kepada orang-orang Yahudi yang memberikan reaksi pada pengajaran-Nya. Waktu itu adalah hari raya Pondok Daun dan Yesus juga berada di Yerusalem dan kemudian meng-

${ }^{11}$ Plato, Phaedo 92a-b: Complete Works, 79-80.

${ }^{12}$ Untuk mengetahui lebih lanjut peran filsafat di dalam Kristen, bisa dilihat dalam artikel, Edison R. L. Tinambunan, "Filsafatisasi Kristiani atau Kristianisasi Filsafat," Diskursus 16, No 1 (April 2017), 1-22. Https://journal.driyarkara.ac.id/index.php/diskursus/article/view/36.

${ }^{13}$ Pemikiran filosofis Plotinus bisa dilihat dalam, Plotinus, Enneadi, ed. Giuseppe Faggin (Milano: Bompiani, 200).

${ }^{14}$ Agustinus berasal dari Hippo, lahir 354 dan meninggal 430. 
ajar di Bait Allah. Orang-orang Yahudi heran akan pengajarannya dan meragukan pengetahuannya, karena ia tidak mendapatkan pembelajaran untuk menjadi rabi (guru). ${ }^{15}$

Agustinus kemudian menafsirkan perkataan Yesus ini (Yoh 7:17) dengan mengatakan bahwa dalam hidup keagamaan iman berhubungan dengan nalar. Konteks yang hendak ditekankan Agustinus dari perkataan Yesus itu adalah "akan tahu entah ajaran-Ku dari Allah atau dari-Nya sendiri" yang merujuk penggunaan nalar. Rumusan Agustinus dalam penafsiran Yoh 7:17 adalah "Ergo noli quaerere ingellegere ut credas, sed crede ut intellegas" yang artinya adalah "Dari sebab itu sebenarnya tidak bernalar untuk beriman, tetapi hendaklah (engkau) beriman untuk bernalar." "Baginya dalam kutipan Yoh 7:17 terdapat dua pengertian yang mau disampaikan. Pengertian pertama adalah "barang siapa mau melakukan kehendakNya, ia akan tahu entah ajaran-Ku dari Allah atau bukan”. Artinya adalah orang terlebih dahulu memikirkan mengenai kebenaran ajaran yang disampaikan oleh pengajar, lalu kemudian bisa memberikan penilaian apakah ajarannya itu berasal dari Allah atau pendapat subjektif atau bahkan dari ajaran lain. Sikap ini adalah bernalar. Lalu kemudian orang tersebut bisa memutuskan mengikuti ajaran itu atau menolaknya. Pada pengertian pertama ini, orang tersebut dihadapkan pada dua pilihan, yaitu mengikuti ajaran atau menolak atau bisa diartikan juga dengan menjadi orang beriman atau tidak. Pengertian kedua adalah "barang siapa mau melakukan kehendak-Nya". Kalimat berhenti pada poin ini. Pada bagian ini Agustinus mau menunjukkan bahwa orang diberi pengajaran agar orang yang bersama dengan Yesus pada waktu itu bisa memikirkan, sehingga memberikan penilaian dan memutuskan untuk menolak atau menerima perkataan-Nya.

Sebagai orang yang belajar dan menguasai filsafat, Agustinus menyadari bahwa pemikiran platonis mengenai nalar, dari aspek filosofis, adalah benar. Hal yang dibutuhkan saat ini di dalam hidup beragama adalah hubungan iman itu dengan nalar. Secara prinsipil dalam konsep pemikiran Agustinus, baik iman maupun nalar tidak bertentangan sama sekali, tetapi sebaliknya, nalar justru membantu iman untuk memikirkan tentang apa yang diimani, seperti ajaran dan aspek lainnya yang berkaitan dengan iman tersebut.

Agustinus menyadari bahwa dengan pemikiran platonis mengenai nalar, orang sudah bisa hidup baik, karena hidup menurut kebajikan yang pasti akan membawa pada kebaikan. Akan tetapi sebagai orang beriman, Agustinus meyakini bahwa asal dan tujuan manusia bukan iman platonis atau filosofis, tetapi Tuhan Allah. Nalar yang diagungkan oleh konsep pla-tonis yang menjadikan kodrat manusia, mengangkat derajat manusia, bukan hanya bersifat gradasi dari ciptaan lain, tetapi juga sebagai potensi untuk tujuan hidup. Oleh sebab itu, nalar yang dimiliki manusia berdasarkan pemikiran platonis digunakan oleh Agustinus sebagai potensi untuk membuat manusia memikirkan tujuan hidup beragama.

Sebenarnya Agustinus secara tidak langsung bermaksud untuk memberikan superioritas antara iman dan nalar atau gradasi keduanya, karena bagi dia sebagai seorang Kristen menem-

\footnotetext{
${ }^{15}$ Band. Raymond Edward Brown, The Gospel According to John (i-xii), The Anchor Bible (Garden City, New York: Doubleday \& Company, 1966), 312.

${ }^{16}$ Augustinus, In Iohannis Evanglium Tractatus CXXIV, 29,6, Corpus Christianorum Series Latina XXXVI (Turnholti: Brepols, 1954), 286-287.
} 
patkan iman di atas segalanya. Kemudian ia memberikan peran dan manfaat nalar di dalam hidup beriman. Pada saat periode Agustinus hidup, pembelajaran filsafat adalah umum dan setiap orang, apakah itu Kristen atau bukan, pasti belajar filsafat. Berdasarkan situasi sosial ini dan didukung oleh pengalamannya, ia berusaha menjelaskan posisi iman dan peran nalar, agar tidak menyalahgunakannya, apalagi menempatkannya di atas iman. Oleh sebab itu dalam pembahasannya iman ditempatkan lebih dahulu dari nalar, yang tampak dalam rumusan tafsirannya, "beriman untuk bernalar" atau dengan kata lain, nalar memfasilitasi iman.

Pemikiran Agustinus sebenarnya mengamini secara prinsipil pemikiran platonis yang menampilkan tiga aspek dalam diri manusia, yaitu tubuh, kebajikan dan nalar dan bagaimana ketiga hal tersebut berhubungan. Akan tetapi, berdasarkan pembahasan kerangka pemikiran Agustinus, iman menjadi unsur baru, yang bahkan menjadi lebih penting dibandingkan dengan nalar. Iman inilah yang mengorganisir baik itu nalar, kebajikan dan tubuh manusia. Persoalannya sekarang adalah, bagaimana keempat unsur manusia itu berhubungan? Bagaimana Agustinus menjelaskannya? Prinsip dasar adalah bahwa tujuan beriman adalah untuk keselamatan jiwa. Segala aspek lain adalah untuk tujuan keselamatan itu. Fungsi nalar dalam Agustinus diterangkan oleh W. Gundersdorf von Jess yang membuat suatu studi mengenai hubungan iman dan nalar. Tulisan itu mengungkapkan bahwa nalar adalah suatu propaedeutic $^{17}$ untuk iman, yaitu nalar membuka jalan untuk iman agar lebih mengerti dan mendalami, dengan demikian iman menjadi dinamis, yang membutuhkan pemahaman secara terus menerus. ${ }^{18}$ Keberadaan iman adalah tetap lebih dulu, karena rahmat. Oleh sebab itu pada dasarnya nalar tidak bertentangan dengan iman, akan tetapi bahkan memfasilitasinya. Mengenai kebajikan, dalam platonis sebagai buah dari nalar, dalam pemikiran Agustinus, kebajikan itu diilahikan sehingga menjadi ungkapan iman yang berasal dari Tuhan Allah, karena pada dasarnya kebajikan adalah selalu baik.

Hal mendasar saat ini adalah alasan Agustinus menempatkan iman memiliki posisi lebih tinggi dari nalar. Iman itu adalah ilahi. Dengan kualitas ini, pada dasarnya adalah selalu baik dan segala kebajikan dihasilkannya. Kebajikan yang dihasilkan oleh nalar pun, berada di dalam kualitas iman. Oleh sebab itu secara prinsipil, ia memiliki tempat prioritas di dalam diri manusia dan mengorganisasi hidup beriman. Dengan konteks ini bisa dikatakan iman untuk nalar yang sesuai dengan tafsirannya pada Yoh 7:17 yang telah ditunjukkan sebelumnya, sehingga dalam perjalanan waktu rumusan pemikiran Agustinus ini tetap dipertahankan.

Kemudian konsep Agustinus mengenai iman untuk nalar diikuti oleh Anselmus Canterbury ${ }^{19}$ yang rumusannya mirip, yaitu neque enim quaero intelligere ut credam, sed credo ut ingelligam (sesungguhnya saya tidak bernalar untuk beriman, tetapi saya beriman untuk bernalar), yang secara konseptual adalah sama dengan Agustinus, tetapi subyek dan bentuk ka-

\footnotetext{
${ }^{17}$ Istilah propaedeutic tetap dipertahankan, karena bahasa Indonesia belum menggunakannya sebagai kata serapan. Kata propaedeutic berasal dari bahasa Yunani (propaideutié) yang artinya pembelajaran yang mendahului atau pembelajaran persiapan sebelum masuk pada pembelajaran yang akan dilaksanakan.

${ }^{18}$ W. Gundersdorf von Jess, "Reason as Propaedeutic to Faith in Augustine", International Journal for Philosophy of Religion 5 (1974), 227-228. Bdk. R. E. Cushman, "Faith and Reason in the Thought of St. Augustine", Church History 19, No. 4 (December 1950), 271-294.

${ }^{19}$ Anselmus lahir di Aosta, Italia 1033 kemudian menjadi uskup di Caterbury, Inggris dan meninggal 1109.
} 
limat berbeda. ${ }^{20}$ Kemudian konteks dan titik tolak pembahasan juga berbeda. Agustinus menafsirkan Yoh 7:17 sebagai titik tolaknya, sementara itu Anselmus Kej 1:27 "Maka Allah menciptakan manusia itu menurut gambar-Nya, menurut gambar Allah diciptakan-Nya dia." Anselmus mau menekankan posisi penciptaan manusia yang adalah gambaran Allah yang membedakannya dari ciptaan lainnya. Baginya, gambaran ini adalah kekhasan manusia yang menjadi kodratnya. Gambaran itu dinyatakan dengan nalar yang mengikuti pemikiran platonis. Anselmus juga menekankan posisi iman yang adalah lebih tinggi dari nalar, karena bernalar bukan untuk beriman, tetapi beriman untuk bernalar. Allah menciptakan manusia seperti itu agar iman menjadi pusat dan tujuan nalar.

René Descartes dengan metodenya Cogito ergo sum (saya berpikir, karena itu saya ada) bisa dikatakan satu garis dengan Agustinus dan Anselmus. Konsep ini adalah metode filosofis Descartes yang merupakan tahap terakhir. Dalam konsep ini, ia tidak menyertakan iman, akan tetapi ia bisa mengidentifikasi bahwa kodratnya manusia adalah nalar. Melalui nalar ini ia bisa melihat keberadaan yang lebih sempurna dari dirinya yang bagi dia disebut dengan adikodrati yang melebihinya yang tidak dipahaminya yang disebutnya dengan Tuhan. ${ }^{21}$ Dalam konteks ini Descartes menjadikan nalar itu untuk mencapai kesadaran keberadaan Tuhan yang lebih sempurna dari dirinya. Dari Agustinus, Anselmus dan Descartes dapat dilihat bahwa nalar sebagai sarana untuk beriman, kemudian nalar membantu iman untuk memperoleh kebenaran dan memperdalamnya.

\section{Perkembangan Iman untuk Nalar}

Dalam perkembangan studi mengenai iman dan nalar praktis tetap mengikuti konsep yang telah dikemukakan oleh Agustinus dan diikuti oleh Anselmus dan Descartes dalam nuansa lebih luas dengan mendasarkan konsep bukan saja bertitik tolak dari Yohanes, tetapi juga dari Kitab Kejadian, bahkan metode berfilsafat. Artinya adalah aliran teologis yang dimulai Agustinus tetap dipertahankan yang dapat dilihat dalam beberapa penelitian berikut ini, walau pun juga kadang memberi penekanan pada nalar.

Russel J. De Simone menulis satu artikel di dalam Ensiklopedi patristik sehubungan dengan iman dan nalar menurut Agustinus. Dalam tulisan itu ia sebenarnya tidak memberikan sesuatu yang baru, kecuali hanya menerangkan konsep pemikiran Agustinus crede ut intelligas. Menurut De Simone, iman tetap menjadi pusat dan tujuan, dan nalar adalah sarana untuk membawa orang menuju kebenaran dalam hidup beragama. Ia kemudian menambahkan bahwa melalui nalar, orang sampai pada pengenalan dan pengetahuan akan iman yang juga memerlukan pemikiran dan analisis yang berkaitan dengan kebutuhan hidup. Oleh sebab itu, nalar bertindak sebagai arah atau petunjuk untuk iman. ${ }^{22}$ Dalam hidup beragama, sikap seperti ini mutlak dibutuhkan agar tidak salah arah.

\footnotetext{
${ }^{20}$ Anselmus, Prolegomena 1, Opera Omnia, ed. J. P. Migne, Tomus Primus, Paris: Dicta D’Amboise, 1853, 227.

${ }^{21}$ René Descartes, Diskursus \& Metode, penerj. Ahmad Faridl Ma’aruf (Banguntapan Jogjakarta: IRCiSoD, 2012), 75-77.

${ }^{22}$ Russel J. De Simone, "Fede", in Dizionario Patristico e di Antichità Cristiane, Institutup Patristicum Augustinianum Roma, diretto da Angelo di Berardino (Genova: Marietti, 1994), 1346.
} 
Salah satu studi yang pada tahun enam puluhan adalah Jules M. Brady. Walaupun penelitiannya ini sudah dilakukan agak lama dari sekarang, tetapi konten masih tetap aktual sampai dengan saat ini. Ia pada awalnya sangat menekankan kerangka pemikiran platonis dan bahkan sangat mengagungkannya mengenai nalar, yang sebenarnya sangat membantu iman dalam hidup keagamaan. Brady mengatakan bahwa nalar merupakan suatu imprint (jejak) dari nalar abadi (yang tertinggi atau logos) yang hanya dimiliki oleh manusia. Fungsinya adalah sebagai suluh untuk kepentingan hidupnya. ${ }^{23}$ Dalam pemikiran Agustinus dan juga pemikiran platonis, nalar itu perlu dikembangkan dengan pemberian pembelajaran, kebajikan dan contoh hidup. Oleh sebab itu Brady yang mengikuti kerangka pemikiran Agustinus, mengatakan bahwa nalar itu adalah bagaikan semai yang membutuhkan pemeliharaan melalui pendidikan agar memiliki fungsi yang baik dan menghasilkan untuk iman. Dalam alur pikir ini, nalar yang ada di dalam manusia, adalah suatu potensi (yang dapat dikembangkan) untuk mengarahkan hidup setiap orang. Jika orang menggunakan dan memanfaatkan potensi itu dengan baik, maka ia sungguh menjadi manusia sesuai dengan kehendak yang tertinggi. Akan tetapi, jika orang tersebut tidak menggunakan potensi atau bahkan sebaliknya, menyalah gunakan potensi tersebut, maka ia tidak hidup sesuai dengan yang tertinggi atau kalau mengikuti konsep pemikiran platonis, kehilangan kodratnya. Hasil dari potensi yang dikembangkan itu adalah kebajikan yang dengan sendirinya sesuai dengan buah hasil dari iman yang berkembang di dalam dirinya. ${ }^{24}$

Eugene TeSelle membuat suatu penelitian iman dan nalar di dalam buku Ensiklopedia Pemikiran Agustinus dari Abad ke Abad. Walaupun buku ini berbentuk ensiklopedia mengenai entri pemikiran Agustinus, tetapi dari aspek bentuk dan isi penulisan lebih mengarah pada suatu tulisan ilmiah dalam bentuk bunga rampai. Menurut penelitiannya, nalar dalam pemikiran Agustinus dipengaruhi oleh Plotinus. ${ }^{25}$ Kemudian ia mengungkapkan bahwa bagi Agustinus iman adalah superior dari nalar karena diterangi oleh yang ilahi. Hal ini menepis pemikiran orang yang hanya mengandalkan pemikiran dan mengesampingkan iman. Atau sebaliknya, dalam mengunggulkan iman, bukan berarti nalar dan ilmu pengetahuan tidak berarti, tetapi bermanfaat untuk iman di dalam berbagai aspek. ${ }^{26}$ Sehubungan dengan studi iman dan nalar, saat ini tidak selalu dihubungkan dengan konsep pemikiran Agustinus yang telah dibahas sebelumnya, tetapi juga telah dibahas oleh para peneliti agama lain, seperti Islam. Alasannya adalah bahwa baik iman maupun nalar selalu berada di dalam hidup beragama. Oleh sebab itu kedua hal ini membutuhkan pembahasan, agar tidak salah kaprah yang bisa merendahkan satu dengan lainnya.

Maureen Junker-Kenny membuat suatu penelitian mengenai nalar dalam kaitannya dengan agama. Ia sama sekali tidak menghubungkannya dengan pemikiran Agustinus. Dalam

\footnotetext{
${ }^{23}$ Jules M. Brady, “St. Augustine's Theory of Seminal Reasons”, The New Scholasticism 38, No. 2 (April 1964), 154

${ }^{24} J u l e s$ M. Brady, "St. Augustine's Theory of Seminal Reasons", 155-157.

${ }^{25}$ Poin Plotinus yang memengaruhi Agustinus menurut Eugene TeSelle adalah Enneadi, 4, 8,4, Porfirio Vita di Plotino, Testo Grego a fronte, ed. Roberto Radice (Milano: Edizione Bompiani, 2000), 765-766.

${ }^{26}$ Eugene TeSelle, "Faith", in Augustine through the Ages, An Encyclopedia, ed. Allan D. Fitzgerald (Michigan / Cambridge: William B. Eerdmans Publishing Company-Grand Rapids, 1999), 347-348.
} 
penelitiannya itu ia berpendapat bahwa orang beragama hidup di belakang penalaran. Tujuannya adalah untuk menemukan, menganalisis dan memutuskan kebenaran akan yang diimani dan dengan cara itu mendapatkan suatu ajaran atau yang sering dikenal dengan doktrin. Dan satu hal yang perlu dilihat dari penelitiannya ini adalah bahwa doktrin itu bukan saja bersifat religius, tetapi juga sekuler karena orang beriman itu selalu berhubungan dengan kedua aspek kehidupan tersebut. ${ }^{27}$ Bagi Junker-Kenny, perkembangan zaman, ilmu pengetahuan dan fenomena baru pasti akan muncul, karena ilmu dan dunia ini adalah dinamis. Oleh sebab itu, nalar dibutuhkan untuk menafsirkannya agar menemukan kebenaran yang sesuai dengan iman. Bahkan nalar juga dibutuhkan untuk menerjemahkannya dalam pengertian iman, dan untuk itu nalar hendaknya digunakan untuk meresapi kebenaran iman. ${ }^{28}$ Akan tetapi satu hal yang perlu diingat, katanya, bahwa nalar bukan bermaksud untuk membenarkan tetapi mengerti fenomena tersebut, mendapatkan kebenaran dan juga mempertahankan agama dari aspek negatif yang ditimbulkannya, seperti fundamentalisme yang memperalat agama. ${ }^{29}$

Dua studi Islam berikut ini melengkapi pembahasan iman dan nalar, karena agama ini juga bergaul dengan pemikiran filosofis. Studi pertama adalah Frank A. Stone yang memulai penelitiannya mengenai hubungan filsafat tentang nalar dengan Islam yang bertitik tolak dari pemikiran filosofis Plato dan filsuf yang mengikutinya. Menurut dia melalui nalar, kebenaran iman akan dicapai. ${ }^{30}$ Ia menyimpulkan penelitiannya dengan mengatakan bahwa iman membutuhkan nalar di dalam Islam, terlebih-lebih di dalam edukasi untuk penyampaian kebenarannya. ${ }^{31}$

Peneliti lain adalah A. E. Souaiaia yang di dalam kajiannya juga terlebih dahulu memberikan pemaparan Islam yang berkontak dengan filsafat dalam perkembangan sejarah. Kristen memang terlebih dahulu berkontak dengan filsafat, karena secara kronologis, lebih dahulu lahir. Ia melihat bahwa sejak awal, Kristen mampu menghubungkan nalar dalam kaitannya dengan iman. Bahkan berteologi tidak akan memiliki arti kalau tidak menggunakan nalar. Islam juga berteologi. Artinya adalah bahwa dalam teologi itu nalar dibutuhkan untuk menghasilkan pemikiran dan studi sistematis akan agama yang memberikan kebenaran iman. Nalar dalam berteologi berusaha untuk memberikan inspirasi dan sikap ingin tahu lebih banyak dan mendalam akan iman tersebut. Untuk itu aspek ilmu penunjang untuk berteologi itu dibutuhkan dan salah satu di antaranya adalah filsafat. ${ }^{32}$ Ia kemudian menambahkan bahwa tujuan nalar adalah untuk kesetiaan ortodoksi yang sesuai dengan iman dan tradisi. Dengan demikian konseptualisasi akan Allah dan penjelasan mengenai doktrin yang dihasilkan konsep tersebut dapat dipertanggungjawabkan. ${ }^{33}$

\footnotetext{
${ }^{27}$ Maureen Junker - Kenny, "Witnessing of Mutual Translation? Religion and the Requirements of Reason", Concilium 1 (2011), 105.

${ }^{28}$ Maureen Junker - Kenny, "Witnessing of Mutual Translation?”, 111.

${ }^{29}$ Maureen Junker - Kenny, "Witnessing of Mutual Translation?”, 111-112.

${ }^{30}$ Frank A. Stone, "The Muslim Faith and Reason: Discussion and its Implications for Islamic Education," The Muslim World 60, No. 1 (1970), 318.

${ }^{31}$ Frank A. Stone, "The Muslim Faith and Reason", 320.

${ }^{32}$ A. E. Souaiaia, "Reasoned and Inspired Beliefs: A Study of Islamic Theology," The Muslim World 97, No. 2 (1970), 332-333.

${ }^{33}$ A. E. Souaiaia, "Reasoned and Inspired Beliefs", 345.
} 


\section{Nalar untuk Iman di dalam Kehidupan Beragama}

Sampai dengan bagian ini, pembahasan mengenai iman dan nalar bisa dikatakan terbatas dalam arti karena masih meninjau dari aspek filosofis, mulai dari alur pemikiran Agustinus dan perkembangannya. Dari pembahasan tersebut bisa dikatakan bahwa nalar adalah bagian yang mendasar dalam diri manusia, lalu kemudian Agustinus membuka kerangka pikir dengan iman untuk nalar. Pada pembahasan berikut, kerangka konsep adalah nalar dan iman sebagai temuan penelitian ini.

\section{Nalar - Kebajikan}

Dari aspek filosofis, nalar adalah sangat mendasar, yang telah dilihat dalam pemikiran platonis. Hal pertama yang perlu diperhatikan dari platonis ini adalah bahwa pada dasarnya nalar tidak bersifat dikotomi dengan kebajikan di dalam diri manusia. Artinya adalah di dalam diri manusia semestinya tidak ada dualisme. Memang dalam konsep platonis, iman tidak dihadirkan, akan tetapi nalar dihadapkan pada kebajikan yang diperlukan oleh tubuh yang adalah materi. Bagi Plato, materi itu bisa menjadi jahat dan bisa juga menjadi baik, tergantung penggunaan nalar. Dalam hidup, materi itu diarahkan pada kebaikan melalui kebajikan. Oleh sebab itu, nalar dalam diri manusia membuat keharmonisan dengan kebajikan untuk mengarahkan dan mengorganisasi hidup agar sesuai dengan kodratnya, yaitu sesuai dengan logos. Inilah misi nalar dalam kehadirannya di dalam diri manusia untuk membuatnya menjadi bajik.

Kebajikan yang adalah buah dari nalar, apa pun bentuknya, pada prinsipnya adalah selalu baik. Pendidikan dan contoh hidup dibutuhkan oleh nalar agar manusia lebih bajik. Dalam pemikiran platonis, semakin orang terdidik atau memiliki pendidikan lebih tinggi, mestinya orang tersebut semakin lebih bajik. Akan tetapi dalam kenyataan, jangankan orang yang berpendidikan tinggi, orang biasa saja pun bisa saja tidak bajik. Atau bahkan orang berpendidikan bisa saja memiliki kehidupan lebih jahat dari orang yang tidak berpendidikan. Apakah ini bukan suatu dikotomi? Apakah itu bukan dualisme di dalam diri manusia?

Mengikuti pola pikir platonis, yang pada dasarnya manusia itu adalah baik karena memiliki kebajikan yang berdasar dari nalar untuk membimbing kehidupan manusia, berarti manusia selalu terarah pada kebaikan; atau dengan kata kebalikannya, mestinya manusia tidak ada yang jahat, karena tidak sesuai dengan kodratnya. Orang bisa jatuh pada kejahatan karena ia menyalahgunakan nalar yang dimiliki. Atau dengan kata lain, ia menyimpang dari kodratnya. Secara prinsipil kebajikan itu tetap berada di dalam diri orang yang berbuat jahat, akan tetapi untuk kepentingan pribadi, atau melihat kejahatan itu lebih menyenangkan atau menguntungkan daripada kebajikan, sehingga orang tersebut meninggalkan kebajikannya. Dengan cara itu orang tersebut membiaskan kebajikan ke arah yang lain dan memilih kejahatan. Misalnya, jika ada orang melaksanakan korupsi, maka ia melihat korupsi dan hasilnya sebagai suatu kebaikan karena alasan kenikmatan, kepuasan, keindahan. Orang tersebut bukan berarti tidak melihat bahwa korupsi itu jahat, tetapi ia toh melaksanakannya. Bukan berarti juga ia tidak memiliki kebajikan. Ia tetap memilikinya, akan tetapi karena banyak aspek, kebajikan itu tersamar oleh perbuatan yang dianggap menyenangkan. Nyatanya ada orang 
bertobat dari kejahatan, yang berarti kebajikan yang sebelumnya tersamar, menjadi jelas kembali. Ini adalah salah satu contoh dari banyak yang sering dilakukan manusia.

Berdasarkan pemikiran filosofis ini, nalar dan kebajikan membentuk keharmonisan yang sangat baik di dalam diri manusia. Mengikuti pola pikir ini bisa dikatakan bahwa jika orang mengikuti nalar saja, maka ia akan menjadi manusia sempurna menurut platonis, karena orang tersebut hidup sesuai dengan kebajikan yang dengan sendirinya adalah suatu kebaikan. Itu berarti bahwa ia hidup menurut kodratnya (logos). Dengan alasan inilah para filsuf selalu berusaha sebaik mungkin memberikan pembelajaran filsafat kepada murid-muridnya supaya menjadi manusia sofia (bajik) di dalam hidup. Dengan cara itu manusia hidup sesuai dengan kodratnya di dunia ini. Mengikuti pemikiran platonis ini bisa dikatakan bahwa jika setiap orang hidup sesuai dengan nalarnya, secara otomatis kebajikan hadir di dalam setiap orang yang menjadi prinsip hidup komunal.

\section{Nalar untuk Iman}

Hubungan iman dan nalar dalam pemikiran Agustinus, Anselmus, Descartes dan peneliti sesudahnya yang telah dilihat sebelumnya, juga menjadi salah satu bagian acuan dari tulisan ini. Kerangka pikir itu bisa dirumuskan seperti berikut "crede ut intelligas - engkau percaya untuk bernalar" (menurut Agustinus) atau "credo ut intelligam - saya percaya untuk bernalar" (menurut Anselmus). Konten kedua frase mereka pada dasarnya adalah sama, perbedaannya hanya terletak pada subyek, sehingga rumusan kalimatnya berbeda sesuai dengan struktur bahasa latin. Dari frase ini, penekanan yang ingin mereka tampilkan adalah iman yang menjadi puncak, tujuan dan payung nalar. Jika seseorang memiliki iman, maka ia semestinya memiliki kemampuan menyertakan nalar dan aspek kemanusiaannya. Artinya adalah bahwa iman menjadi sumber hidup, dan dari sana lahir kebajikan. Dengan alasan inilah, iman ditempatkan terlebih dahulu lalu diikuti oleh nalar. Prinsip itu juga menempatkan iman dalam gradasi lebih tinggi dibandingkan nalar, dan secara prinsipil iman bisa mengarahkan nalar untuk tujuannya. Sementara itu Descartes dengan frasenya Cogito ergo sum, menjadikan nalar untuk pengenalan Tuhan. Dalam hidup keagamaan, hal ini nalar adalah mendasar, karena iman memang seharusnya di atas segalanya dari yang lain, termasuk nalar. Kerangka pikir ini bisa dirumuskan dengan singkat: beriman untuk bernalar atau iman untuk nalar.

Penelitian yang sedang dilaksanakan ini menempatkan nalar terlebih dahulu, lalu kemudian diikuti oleh iman yang tujuan utamanya bukan untuk menomorduakan iman atau dalam arti membuat suatu gradasi antara iman dan nalar, dan bukan juga bermaksud untuk merendahkan hidup beragama, akan tetapi mau menunjukkan fungsi nalar dalam kaitannya dengan iman dalam hidup beragama. Berkat nalar yang tepat, seperti logika, pengertian, ilmu pengetahuan dan lainnya, orang dapat membuat suatu pilihan pada kebaikan dan menghindarkan kejahatan untuk mendukung hidup keagamaan yang dianut. Penelitian ini bukan berarti menyangkal pendapat sebelumnya (Agustinus, Anselmus, Descartes dan pengikut studi lainnya), akan tetapi membuat penelitian dari sudut nalar yang juga penting untuk iman.

Diperkaya pembahasan Plato dan realitas, manusia sesungguhnya memiliki kekhususan yang sangat membedakannya dari ciptaan lain. Berkat nalar yang dimilikinya, menjadikan hi- 
dup dan dunia dinamis melalui berbagai bidang ilmu pengetahuan. Berdasarkan pemikiran platonis, nalar juga berarti membuahkan kebajikan. Hal ini menunjukkan bahwa nalar memberikan aspek penting untuk kebaikan dan kepentingan kehidupan manusia. Perkembangan ilmu pengetahuan semestinya dengan sendirinya juga memberikan kebaikan di dalam hidup beragama. Contoh konkret, orang yang belajar ilmu tafsir, ia tidak cukup hanya memperdalam aspek yang berkaitan dengan penafsiran itu saja, tetapi juga ia dibantu oleh ilmu pengetahuan lain, seperti historis dan segala aspeknya, bahasa dan segala aspeknya, konteks dengan segala aspeknya, budaya dan segala aspeknya dan lainnya. Semuanya ini membutuhkan nalar. Demikian juga dengan pembelajaran lain, nalar sangat dibutuhkan.

Secara manusiawi, apa yang dikatakan oleh Plato adalah benar dalam kaitannya dengan kebajikan. Hal ini bisa dilihat misalnya, orang yang berpendidikan tinggi adalah bukan garansi menjadi bajik, bisa saja orang yang berpendidikan rendah menjadi lebih bajik. Tidak sulit menemukan orang berpendidikan tinggi tidak memiliki kebajikan dan tidak sulit juga menemukan orang tidak berpendidikan tinggi memiliki kebajikan. Akan tetapi orang yang bernalar akan membuahkan kebajikan, yang tidak memandang apakah seseorang itu berpendidikan tinggi atau rendah. Artinya adalah melalui nalar, orang dijadikan bajik. Bisa dikatakan bahwa kriteria nalar itu adalah bentuk kebajikan yang diungkapkan di dalam hidup yang tidak terikat pada pemilikan tinggi atau rendah pendidikan.

Dalam praktik hidup, nalar selalu dibutuhkan orang, yang setiap saat selalu mengambil kebajikan. Apalagi saat ini, Indonesia dan juga dunia dilanda pandemi Covid-19 (Corona). Sikap bajik baik itu pemerintah, pemimpin agama, umat beriman maupun seluruh masyarakat sangat dibutuhkan. Memperhatikan seruan pemerintah yang telah dikutip sebelumnya melalui Presiden Joko Widodo, salah satu poin yang rentan untuk penularan pandemi sekarang adalah perkumpulan berskala besar yang biasanya dilakukan di rumah ibadah. ${ }^{34}$ Masyarakat diajak untuk bernalar agar menjadi bajik untuk melaksanakan protokol yang telah ditentukan. Sehubungan dengan himbauan itu, Kristen beribadah dari rumah dengan terang teologis Kristen perdana yang telah melaksanakannya lebih dahulu bdk. (Kis 2:41-47; 4:32-37) dan bahkan inilah identitas gereja Kristen awal. Dalam praktik, peraturan Presiden sering dilanggar bahkan diprotes oleh sebagian masyarakat, dan salah satu klaster penyebaran Covid-19 adalah rumah ibadah, seperti yang diungkapkan oleh Tri Rismaharini. ${ }^{35}$ Jika perkataan Tri Rismaharini ini adalah benar, maka umat beragama membutuhkan nalar agar bersikap bajik sehubungan dengan pelaksanaan peribadahan dan termasuk juga ritualnya. Inilah salah satu contoh praktik hidup yang membutuhkan nalar dari umat beragama untuk melaksanakan kebajikan di dalam hidup.

\footnotetext{
${ }^{34}$ Band. Ihsanuddin, "Jokowi: Kerja dari Rumah, Belajar dari Rumah, Ibadah di Rumah Perlu Digencarkan”, https://nasional.kompas.com/read/2020/03/16/15454571/jokowi-kerja-dari-rumah-belajar-darirumah-ibadah-di-rumah-perlu-digencarkan (29-4-2020).

${ }^{35}$ Ghinan Salman, "Risma: Ada 16 klaster Covid-19 di Surabaya Menjangkiti 4.818 Orang”, Kompas, Oliver Purba (Ed.), 10 Mei, 2020, https://surabaya.kompas.com/read/2020/05/10/15474311/risma-ada-16klaster-covid-19-di-surabaya-menjangkiti-4818-orang?page=all\#page2 (11-5-2020).
} 
Dari berbagai aspek, terlebih dilihat dari teologi gereja, beribadah di rumah atau dari rumah pasti sulit untuk diterima. Dari segi iman, membutuhkan tempat peribadahan dan peribadahannya itu sendiri, tetapi situasi sosial yang tidak kondusif saat ini membutuhkan nalar untuk membuat suatu pilihan dan keputusan. Dalam situasi aktual seperti inilah umat beriman membutuhkan nalar agar tidak salah langkah yang bisa merugikan bukan hanya diri sendiri, tetapi juga orang dekat, jemaat lainnya dan bahkan masyarakat Indonesia pada umumnya.

Prinsip mementingkan Tuhan Allah dari yang lain adalah benar sebagai umat beragama. Lebih menakuti Tuhan Allah dari pada yang lain adalah juga sangat benar sebagai sikap beriman. Akan tetapi, manusia yang hidup di dunia ini, masih berhubungan dengan orang lain dan juga fenomena yang sedang terjadi. Bernalar adalah sikap yang dibutuhkan yang bukan berarti mengurangi kualitas iman, tetapi menjernihkannya untuk apa yang dilakukan dan yang tidak dilakukan. Dengan demikian, bernalar membuat orang beragama itu menjadi bajik di dalam keputusan untuk kepentingan iman dan orang lain. Kebajikan yang adalah buah dari iman dan hasil dari nalar adalah saluran dari dalam diri orang beragama ke dunia luar diri yang secara otomatis mengidentifikasi kualitas nalar dan iman orang tersebut. Dalam konteks inilah nalar memiliki harmoni dengan iman.

Berkat pemaparan yang telah diberikan, bisa dikatakan bahwa nalar dan iman sama sekali tidak menciptakan dikotomi di dalam hidup beragama. Justru nalar itu mengantar umat beragama untuk memikirkan, menimbang dan akhirnya membuat suatu pilihan yang tidak bertentangan dengan iman. Nalar yang dimiliki oleh manusia, yang menjadi kodratnya menurut pemikiran platonis, selalu membawa orang dan juga umat beragama pada suatu pilihan yang baik dan benar, sehingga tidak ikut arus seperti hoax, provokasi, hasutan dan lainnya yang saat ini marak di media sosial, melainkan memiliki pendirian yang benar di dalam diri. Jika ada orang membuat suatu keputusan tidak benar atau mengarah pada suatu kejahatan, maka kemungkinan bisa terjadi, antara lain, tidak tahu karena kurang bernalar, menyalah gunakan nalar yang pada prinsipnya tahu, tetapi membiaskan ke tujuan lain yang dianggap lebih baik, padahal pada prinsipnya adalah bukan untuk tujuan itu. Agar umat beragama tidak salah bernalar, maka selalu dibutuhkan pembinaan nalar hingga akhir hidup. Saat ini masalah Covid-19 yang sedang dihadapi, membutuhkan nalar setiap orang, termasuk juga umat beragama. Akan tetapi di kemudian hari fenomena baru pasti akan muncul yang juga membutuhkan nalar. Oleh sebab itu nalar selalu dibutuhkan setiap saat oleh umat beragama untuk membuat suatu pilihan yang harus dan tidak dilaksanakan yang dengan sendirinya untuk kepentingan iman yang dianut yang pasti akan berhubungan dengan orang lain.

\section{Kesimpulan}

Dari pembahasan yang telah diberikan mengenai nalar dan iman, dua rumusan bisa dikatakan, yaitu beriman untuk bernalar dan bernalar untuk beriman. Berkat kedua pendekatan pembahasan tersebut, aspek mana saja yang ditekankan, bisa disimpulkan bahwa nalar dan iman membentuk keharmonisan (tidak bertentangan satu dengan lainnya) di dalam hidup beragama. Berkat perkembangan dan penyajian pembahasan nalar untuk iman memberikan nuansa lebih luas dari penelitian sebelumnya yang bertitik tolak dari iman ke nalar. Dalam suatu kesem- 
patan Plato berkata bahwa orang yang bernalar pasti berbuat kebajikan, tetapi orang yang jahat mengesampingkan kebajikan. ${ }^{36}$ Perkataan Plato membuat nalar menjadi suatu inspirasi, pencerahan, pemahaman, pendalaman di dalam hidup beragama. Hal praktis yang bisa diambil konsep nalar adalah bahwa ia menjadi filter untuk menjernihkan iman di dalam hidup keagamaan, karena melaluinya, orang memikirkan, memutuskan apa yang dilakukan atau dikatakan dan apa yang tidak seharusnya dilakukan atau dikatakan.

\section{Referensi}

Anselmus. Prolegomena. Opera Omnia, Tomus Primus, Accurante J.P. Migne. Paris: Dicta D'Amboise, 1853.

Augustinus. In Iohannis Evanglium Tractatus CXXIV. Corpus Christianorum Series Latina XXXVI. Turnholti: Brepols, 1954.

Brady, Jules M. "St. Augustine's Theory of Seminal Reasons." The New Scholasticism 38, No. 2 (April 1964), 141-158.

Brown, Raymond Edward. The Gospel According to John (i-xii). The Anchor Bible. Garden City, New York: Doubleday \& Company, 1966.

Cushman, R. E. "Faith and Reason in the Thought of St. Augustine." Church History 19, No. 4 (December 1950), 271-294.

De Simone, Russel J. "Fede.” In Dizionario Patristico e di Antichità Cristiane. Institutum Patristicum Augustinianum Roma, diretto da Angelo di Berardino, 1338-1347. Genova: Marietti, 1994.

Descartes, René. Diskursus \& Metode, Diterjemahkan oleh Ahmad Faridl Ma'aruf. (Banguntapan Jogjakarta: IRCiSoD, 2012.

Gundersdorf von Jess, W. "Reason as Propaedeutic to Faith in Augustine." International Journal for Philosophy of Religion 5 (1974), 225-233.

Ihsanuddin. "Jokowi: Kerja dari Rumah, Belajar dari Rumah, Ibadah di Rumah Perlu Digencarkan.” Kompas, Bayu Galih (Ed.), 16 Maret, 2020, https://nasional.kompas.com/read/2020/03/16/15454571/jokowi-kerja-dari-rumahbelajar-dari-rumah-ibadah-di-rumah-perlu-digencarkan (29-4-2020).

Junker - Kenny, Maureen. "Witnessing of Mutual Translation? Religion and the Requirements of Reason.” Concilium 1 (2011), 105-114.

Plato. Complete Works. Edited by John M. Cooper. Indianapolis / Cambridge: Hackett Publishing Company, 1997.

Plotinus. Enneadi. Porfirio Vita di Plotino, Testo Grego a fronte, ed. Roberto Radice. Milano: Edizione Bompiani, 2000.

Salman, Ghinan. "Risma: Ada 16 klaster Covid-19 di Surabaya Menjangkiti 4.818 Orang." Kompas, Oliver Purba (Ed.), 10 Mei, 2020, https://surabaya.kompas.com/read/2020/05/10/15474311/risma-ada-16-klaster-covid-19di-surabaya-menjangkiti-4818-orang?page=all\#page2 (11-5-2020).

Souaiaia, A. E. "Reasoned and Inspired Beliefs: A Study of Islamic Theology." The Muslim World 97, No. 2 (1970), 331-349.

Stone, Frank A. "The Muslim Faith and Reason: Discussion and its Implications for Islamic Education." The Muslim World LX, No. 1 (1970), 314-320.

TeSelle, Eugene. "Faith." In Augustine through the Ages. An Encyclopedia, ed. Allan D. Fitzgerald, 1999, 347-350. Michigan / Cambridge: William B. Eerdmans Publishing Company-Grand Rapids.

\footnotetext{
${ }^{36}$ Plato, Apology 25a-e: Complete Works, 24.
} 
Tinambunan, Edison R. L. "Filsafatisasi Kristiani atau Kristianisasi Filsafat." Diskursus 16, No 1 (April 2017), 1-22.

https://journal.driyarkara.ac.id/index.php/diskursus/article/view/36. 